Article

\title{
Fungal Iron Biomineralization in Río Tinto
}

\author{
Monike Oggerin ${ }^{1, *}$, Fernando Tornos ${ }^{2}$, Nuria Rodriguez ${ }^{2}$, Laura Pascual ${ }^{3}$ and Ricardo Amils ${ }^{1,2}$ \\ 1 Centro de Biología Molecular Severo Ochoa, Nicolás Cabrera 1, 28049 Madrid, Spain; ramils@cbm.csic.es \\ 2 Centro de Astrobiología, Ctra, Torrejón-Ajalvir, Km. 4, 28850 Madrid, Spain; f.tornos@csic.es (F.T.); \\ nrodriguez@cbm.csic.es (N.R.) \\ 3 Instituto de Catálisis y Petroquímica (CSIC), Marie Curie 2, 28049 Madrid, Spain; laura.pascual@icp.csic.es \\ * Correspondence: moggerin@cbm.csic.es; Tel.: +34-91-196-4545; Fax: +34-91-196-4420
}

Academic Editors: Karim Benzerara, Jennyfer Miot and Thibaud Coradin

Received: 1 January 2016; Accepted: 12 April 2016; Published: 18 April 2016

\begin{abstract}
Although there are many studies on biomineralization processes, most of them focus on the role of prokaryotes. As fungi play an important role in different geological and biogeochemical processes, it was considered of interest to evaluate their role in a natural extreme acidic environment, Río Tinto, which has a high level of fungal diversity and a high concentration of metals. In this work we report, for the first time, the generation of iron oxyhydroxide minerals by the fungal community in a specific location of the Tinto basin. Using Transmission Electron Microscopy (TEM) and High Angle Angular Dark Field coupled with Scanning Transmission Electron Microscopy (HAADF-STEM) and Energy-Dispersive X-ray Spectroscopy (EDX), we observed fungal structures involved in the formation of iron oxyhydroxide minerals in mineralized sediment samples from the Río Tinto basin. Although Río Tinto waters are supersaturated in these minerals, they do not precipitate due to their slow precipitation kinetics. The presence of fungi, which simply provide charged surfaces for metal binding, favors the precipitation of Fe oxyhydroxides by overcoming these kinetic barriers. These results prove that the fungal community of Río Tinto participates very actively in the geochemical processes that take place there.
\end{abstract}

Keywords: Río Tinto; biomineralization; fungi; iron mineralization

\section{Introduction}

Río Tinto is a natural rock drainage system generated as the result of subsurface biooxidation of the sub-outcropping volcanogenic massive sulfide ores of the Iberian Pyrite Belt by the activity of chemolithotrophic prokaryotes [1]. As a consequence, water has elevated concentrations of ferric iron, responsible for the oxidation of existing sulfides and the river buffering, and sulfuric acid, responsible for maintaining in solution the high concentration of heavy metals generated by bioleaching $(\mathrm{Fe}, \mathrm{Cu}$, $\mathrm{Zn}, \mathrm{As}, \mathrm{Mn}$, and $\mathrm{Cr}$ ) [2,3].

Río Tinto is considered the largest natural extreme acidic ecosystem on Earth and is a suitable scenario, with the essential geochemical conditions for the precipitation of ferric sulfate minerals related to acid mine drainage (AMD) [4,5]. X-ray diffraction (XRD) and Mössbauer analyses of sediments in old terraces, effluorescences, and crust precipitates have identified different mineral phases along the river, including schwertmannite, goethite, several minerals of the copiapite group, hydronium jarosite and hematite amongst the most important ones [6].

However, what makes Río Tinto a unique extreme acidic environment is the unexpected degree of eukaryotic diversity found in its waters, with fungi as the most diverse among decomposers [7]. A recent characterization of the Río Tinto fungal diversity using samples collected from different sampling stations along the river has rendered more than 350 fungal isolates, which were identified by internal transcribed spacer (ITS) region sequence analysis [8]. This analysis revealed Ascomycetes as 
the most abundant phylum, while Basidiomycetes and Zygomycetes accounted for less than $2 \%$ of the isolates. Of the Ascomycetes, 52\% clustered within the Eurotiomycetes class, while 27\% grouped with the Dothideomycetes, $17 \%$ with the Sordariomycetes, and the rest of the isolates with the Helotiales $(2 \%)$. Metal tolerance tests performed on these isolates showed, in general, a high level of tolerance to toxic heavy metals, much higher than the concentrations detected in the river [9].

In extreme acidic environments with a high content of toxic metals such as Río Tinto, fungal development is possible due to several strategies, such as mineral precipitation (e.g., [10,11]). Since the negatively charged cell walls have the capability to bind metallic cations by non-specific electrostatic interactions, they act as adsorption sites for ions facilitating the nucleation and growth of minerals, contributing to local supersaturation, and decreasing the free energy barriers (thermodynamic) (e.g., [12-15]). Thus, in addition to growth conditions, the resultant minerals depend on the nature of the cell surface, the cellular microenviroment, and the presence of certain reactive anions in the cell walls. Because electrostatic interactions are metabolically independent, cells do not even have to be viable. Dead cells keep the capacity to bind metallic ions $[16,17]$.

In this study, we report the role of fungi that inhabit the wall of a dam in the Río Tinto basin in iron biomineralization processes. Fungi have been implicated in the formation and degradation of minerals [18], but to date Río Tinto mineralogy has been attributed to the chemical characteristics of the system (e.g., [6]). This opens the door to evaluate how fungi, an important part of the microbial community of the Tinto basin, may affect the geochemical characteristics of this natural extreme environment.

\section{Experimental Section}

\subsection{Mineral and Water Analysis}

\subsubsection{TXRF and Ion Chromatography Analyses}

Water samples from the Río Tinto sampling station M13 (Figure 1) were obtained in June 2015 and analyzed by total reflection X-ray fluorescence (TXRF) using a Rich \& Seifert (Ahrensburg, Germany) model EXTRA-II Instrument, and by ion chromatography (IC) in a Dionex DX-600 instrument (Dionex, Sunnyvale, CA, USA) at Interdepartmental Investigation Service (Sidi) at Universidad Autónoma de Madrid.

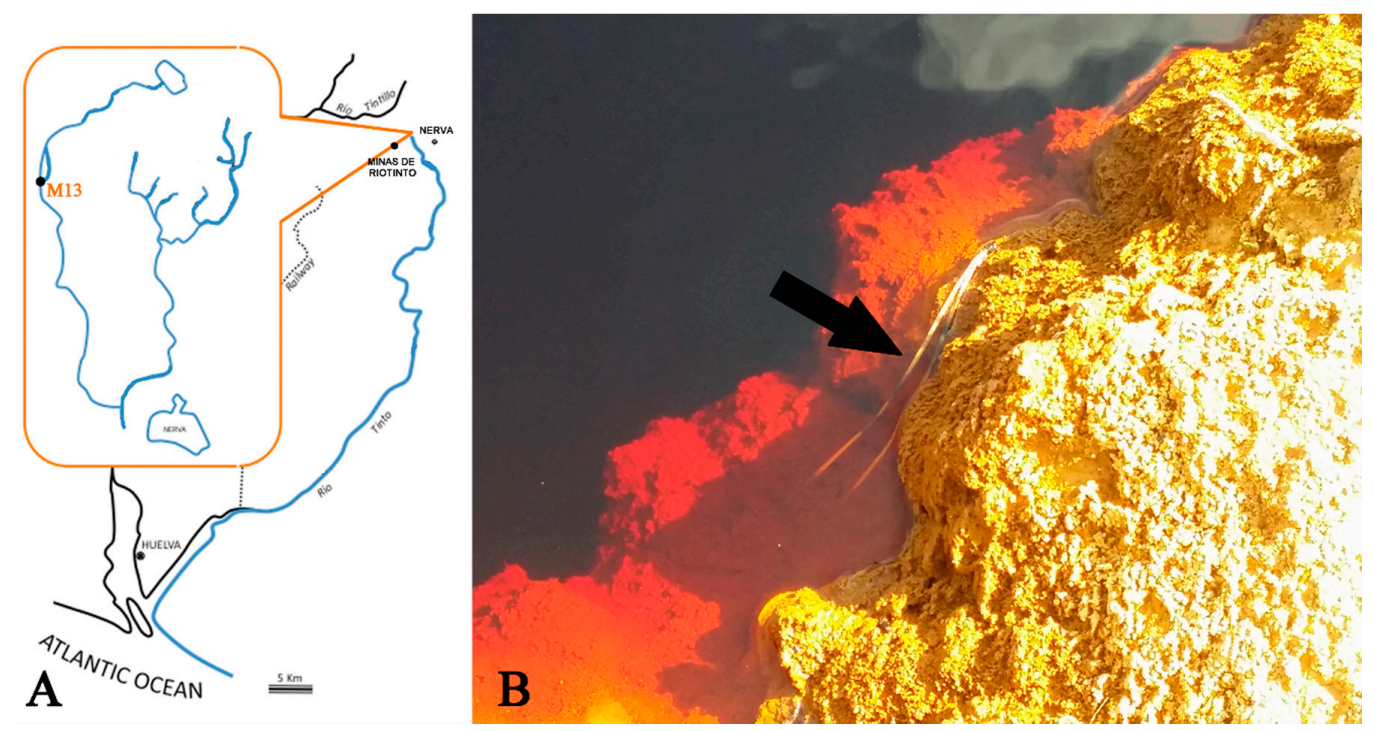

Figure 1. (A) Location of the study area, showing the M13 sampling site. Scale corresponds to $5 \mathrm{~km}$; (B) Field photography of the mineral deposits sampled in this study. The arrow shows a pine needle as scale. 


\subsubsection{X-Ray Diffraction}

XRD analysis was performed on different sediments from the wall of the dam of the same sampling site (Figure 1B). Samples were prepared following the conditions described in [19]. Samples were washed in distilled water, dried at room temperature for $24 \mathrm{~h}$, and ground in agate mortar. Dry powder was analyzed using an X'Pert Diffractometer (Panalytical, Almelo, The Netherlands), with a graphite monochromator and an automatic slit, and were scanned continuously at $1^{\circ} \mathrm{min}^{-1}$ from $5^{\circ}$ to $80^{\circ}$ using a $\mathrm{Cu} \mathrm{K} \alpha$ radiation source. Sediment mineralogy was identified by using the XPowder program for the determination of mineral composition [20].

\subsubsection{Transmission Electron Microscopy}

Sediment samples were also examined by TEM and HAADF-STEM. Samples were prepared at the Centro de Biología Molecular Severo Ochoa (CBMSO) Electron Microscope facility as described in [21]. Ultrathin sections were obtained with a Diatome diamond blade (Diatome-Us, Hatfield, PA, USA) in an Ultracut E (Leica, Wetzlar, Germany) ultramicrotome and collected on 200 mesh Cu grids. Sections were contrasted with uranyl acetate and lead citrate and examined in a JEM1010 TEM (JEOL, Tokyo, Japan) operating at $80 \mathrm{kV}$. Scanning transmission electron microscopy analyses (STEM) were performed in the High Angle Annular Dark Field mode (HAADF), EDX mapping was performed using the STEM mode in a JEM 2010F (JEOL) equipped with an X-ray spectrometer operating at $200 \mathrm{kV}$.

\subsection{Geochemical Modeling}

The Eh vs. SI of key phases expected from the geochemical conditions of the water were calculated using the Geochemist Workbench v.8.0 program [22], using the Wolery database [23].

\subsection{Fungal Isolation, DNA Extraction, ITS rDNA Amplification, and Sequencing}

The fungal diversity that inhabits the wall dam was studied.

Samples of water and sediments from the wall dam from Río Tinto sampling station M13 were collected. Water samples were filtered through $0.22 \mathrm{~mm}$ pore filters; these filters were spread on Potato Dextrose Agar (PDA) containing $100 \mathrm{mg} \cdot \mathrm{mL}^{-1}$ chloramphenicol in sterile conditions. Sediment samples were spread, also, on PDA plus chloramphenicol plates in sterile conditions. PDA plates were incubated at $24^{\circ} \mathrm{C}$, visible mycelium were isolated to new PDA plus chloramphenicol plates in order to obtain axenic fungal isolates. To ensure that these isolates are inhabitants of the Río Tinto and not from contaminant spores, they were grown in potato dextrose broth reconstituted with water from Río Tinto. Those isolates that were able to grow under these conditions were considered inhabitants of the river. Stocks of the isolates were deposited in the Mycological Collection at the Unidad de Microbiología Aplicada (UMA) in the CBMSO (UAM-CSIC) (Madrid, Spain).

DNA extraction, ITS rDNA amplification, and sequencing, were performed according to the procedures described in [21].

\subsection{Sequence Data Analyses}

Forward and reverse sequences were assembled and edited by using Geneious Pro 4.7.6 (Biomatters Ltd., Auckland, New Zealand), and ITS consensus sequences were compared with GenBank database sequences (National Center for Biotechnology Information) by using BLAST (Basic Local Alignment Search Tool, National Center for Biotechnology Information). Phylogenetically related sequences were aligned using the CLUSTAL X (2.0) software [24], and alignments were trimmed using the Se-Al v2.0a11 Carbon software [25]. Cladogram of aligned sequences was performed by distance analysis with neighbor-joining method by using Kimura-2 parameter as distance measure implemented in PAUP* v4.0a146 software (Phylogeny Using Parsimony Analysis) [26], and with a statistical analysis by Bootstrap [27] based on 1000 numbers of replicates. The GenBank accession numbers of the sequences are: M13001 (KU365877); M13002 (KU365878); M13003 (KU365879); M13005 (KU365880); 
M13006 (KU365881); M13007 (KU365882); M13008 (KU365883); M13009 (KU365884); M13010 (KU365885); M13011 (KU365886); M13012-S (KU365887); M13013-S (KU365888); M13014-S (KU365889); M13015-S (KU365890); M13016-S (KU365891); M13017-S (KU365892); M13018-S (KU365893); M13019 (KU365894); M13020-S (KU365895); M13021-S (KU365896); M13022 (KU365897).

\section{Results and Discussion}

The Río Tinto drains the eponymous mine, the world's largest volcanogenic massive sulfide deposit, and one of the major historical mining districts with a history going back to ca. $4000 \mathrm{BC}$ [28]. Sampling station M13 (37 43'17.7" N 6 $33^{\prime} 46.7^{\prime \prime}$ W) (Figure 1A) is one of the deepest locations on the river with a $6 \mathrm{~m}$ water column. It corresponds to a small dam used for water storage for nearby mine operation. The inner wall is completely covered with mineral precipitates reaching between 40 and $60 \mathrm{~cm}$ in thickness (Figure 1B). The physico-chemical characteristics of the water are shown in Table 1. Iron concentration was around $1188 \mathrm{mg} / \mathrm{L}$, and the sulfate reached up to $1700 \mathrm{mg} / \mathrm{L}$, both interpreted as the products of the oxidation of pyrite by chemolithotrophic microorganisms [1]. The $\mathrm{pH}$ was, on average, $2.7 \pm 0.3$. The water also had a high silica content, around $1200 \mathrm{mg} / \mathrm{L}$, possibly related to the interaction of these acidic waters with the widespread felsic volcanic rocks (dacite to rhyolite) in this area. The average temperature of the water was $17^{\circ} \mathrm{C}$.

Geochemical calculations show that the water is supersaturated $(\log Q / K \geqslant 0)$ in different types of clay minerals, quartz, hematite, and goethite (Table 2). Jarosite is only slightly subsaturated $(\log \mathrm{Q} / \mathrm{K}=-0.48)$ and we could not evaluate how hydronium-jarosite behaves due to the absence of solubility data. These results are fairly consistent with the XRD data, which show that the major crystalline phases present in the mineral precipitates on the dam wall primarily include hydronium-jarosite and quartz (Figure 2). Clay minerals and iron oxyhydroxides were not observed. This could be due to the low crystallinity of these phases, which impairs its determination by XRD or it may be just this supersaturation is not enough to overcome the kinetic barrier [22].

Table 1. Main physicochemical characteristics of sampling station M13. Orthophosphate concentration is below the detection limit $(1 \mathrm{mg} / \mathrm{L})$.

\begin{tabular}{|c|c|c|c|c|c|c|c|c|c|c|c|c|c|}
\hline $\begin{array}{c}\text { Sampling } \\
\text { Site }\end{array}$ & $\mathrm{pH}$ & $\begin{array}{c}\text { Eh } \\
(\mathrm{mV})\end{array}$ & $\begin{array}{l}\text { Cond. } \\
\left(\mathrm{mS} / \mathrm{cm}^{2}\right)\end{array}$ & $\begin{array}{c}\mathrm{T} \\
\left({ }^{\circ} \mathrm{C}\right)\end{array}$ & $\begin{array}{c}\mathrm{K} \\
(\mathrm{mg} / \mathrm{L})\end{array}$ & $\begin{array}{c}\mathrm{Fe}^{2+} \\
(\mathrm{mg} / \mathrm{L})\end{array}$ & $\begin{array}{c}\mathrm{Fe}^{3+} \\
(\mathrm{mg} / \mathrm{L})\end{array}$ & $\begin{array}{l}\mathrm{SO}_{4}^{2-} \\
(\mathrm{mg} / \mathrm{L})\end{array}$ & $\begin{array}{c}\mathrm{Cu} \\
(\mathrm{mg} / \mathrm{L})\end{array}$ & $\begin{array}{c}\text { As } \\
(\mathrm{mg} / \mathrm{L})\end{array}$ & $\begin{array}{c}\text { Co } \\
(\mathrm{mg} / \mathrm{L})\end{array}$ & $\begin{array}{c}\mathrm{Si} \\
(\mathrm{mg} / \mathrm{L})\end{array}$ & $\begin{array}{c}\mathrm{Al} \\
(\mathrm{mg} / \mathrm{L})\end{array}$ \\
\hline M13 & 2.7 & 456.4 & 5.5 & 17.1 & 2.0 & 228.6 & 960.3 & 1742.5 & 13.5 & 1.5 & 1.3 & 1269.9 & 299.4 \\
\hline
\end{tabular}

Table 2. Saturation index values for M13 sampling site waters. Parameters used for the calculations: $\mathrm{pH}=2.7 ; \mathrm{T}=17^{\circ} \mathrm{C} ; \mathrm{Eh} / \mathrm{fO}_{2}=4.69 \times 10^{42}$.

\begin{tabular}{cc}
\hline Mineral Phase & SI \\
\hline Nontronite-Ca & 10.0 \\
Clinoptile-Ca & 7.5 \\
Quartz & 2.7 \\
Barite & 1.6 \\
$\mathrm{CuFeO}_{2}(\mathrm{c})$ & 1.1 \\
Beidellite & 0.5 \\
Goethite & 0.16 \\
Hematite & 0.12 \\
Jarosite-K & -0.48 \\
\hline
\end{tabular}

Although bacteria and archaea have received much attention in this type of environment, fungi are also known for playing an important role in biogeochemical cycles carrying out transformations of rocks and minerals, participating in the formation of biominerals and weathering processes, as well as fungal biomass-metal interactions [29]. So, it is therefore important to study fungal diversity inhabiting this area to determine its influence on geochemical cycling. The phylogenetic analysis of the different isolates obtained from different sediments from M13 showed the presence of fungi belonging 
to the Sordariales, Diaporthales, and Hypocreales orders (all of them belonging to the Sordariomycete class), to the Capnodiales order (of the Dothideomycete class), and the Eurotiales order (of the Eurotiomycete class), as shown in Figure 3. The order with the highest number of fungal isolates corresponded to the Eurotiales order that includes Penicillium, Aspergillus, and Talaromyces genera. We also have to emphasize that members of the Dothideomycete class, or black fungi, have been described as slow-growing melanized colonizers of rock surfaces in extreme environments (e.g., [30-32]) being able to tolerate low nutrient availability, fluctuations in temperature, and high solar radiation (e.g., [33]). Fungal isolates belonging to these orders, and the same genera as those isolated in this area of the river, have already been described in weathering of different minerals such as carbonates, silicates, or metal sulfides, in biomeralization and metal-fungal interaction processes, among others (e.g., [18,30,34]).

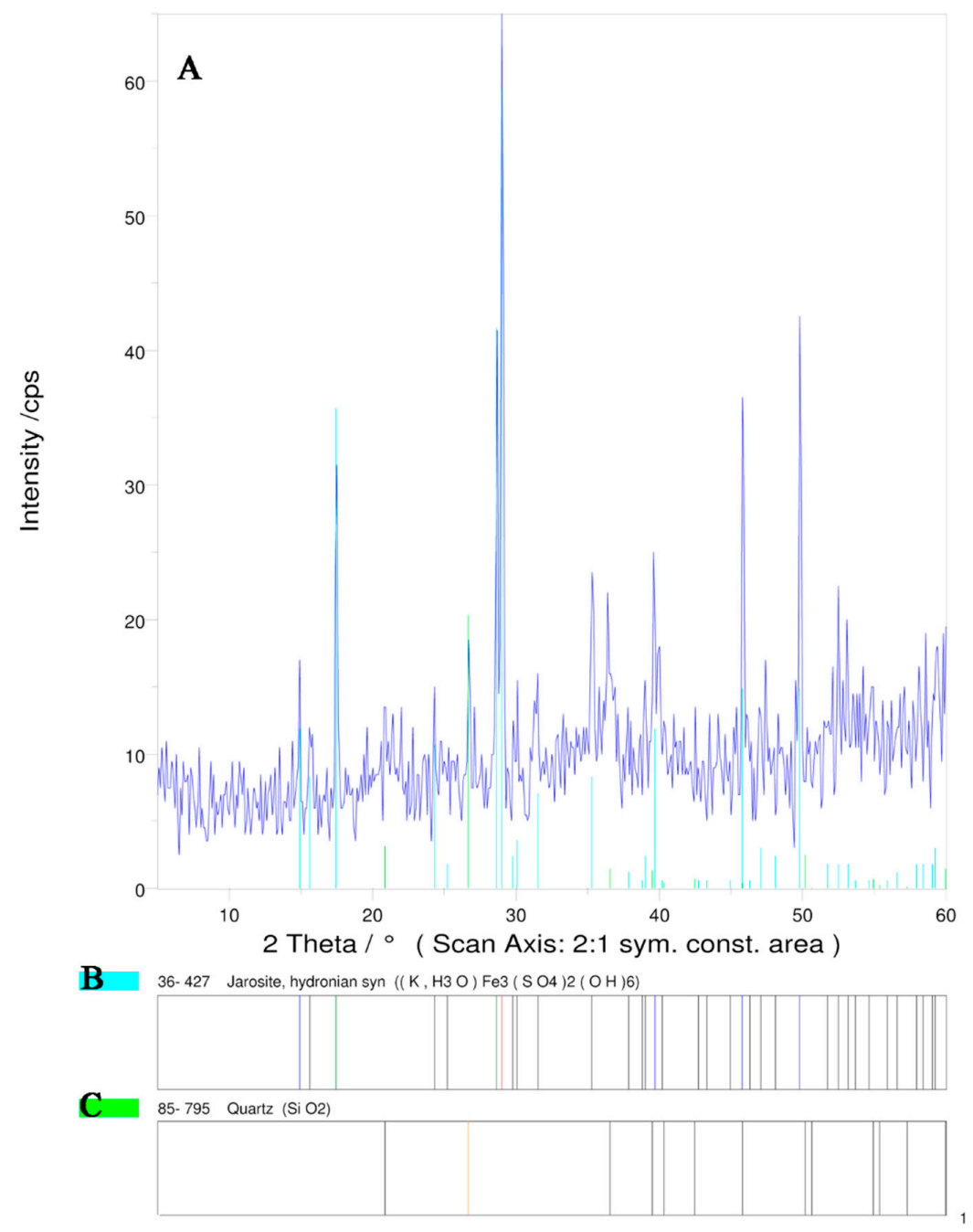

Figure 2. XRD analysis. (A) XRD pattern of the deposits sampled in M13 sampling site; (B) XRD pattern of hydronium jarosite syn; (C) Quartz XRD pattern.

With respect to biomineralization processes, previous studies have focused primarily on the formation of minerals by bacteria. All major microbial groups are capable of immobilizing metal ions and carrying out mineralization processes through organic and inorganic precipitation of secondary associated minerals as well as depositing crystalline material on and within cell walls [31,34,35]. Also, fungi have been reported as an important part of the microbial community of Río Tinto, as well as other mine drainage systems with similar characteristics (e.g., [7,36-38]) So, in a scenario like Río 
Tinto, it is not unreasonable that fungi may be involved in different geochemical cycles, such as the dissolution of certain minerals and the formation of new ones.

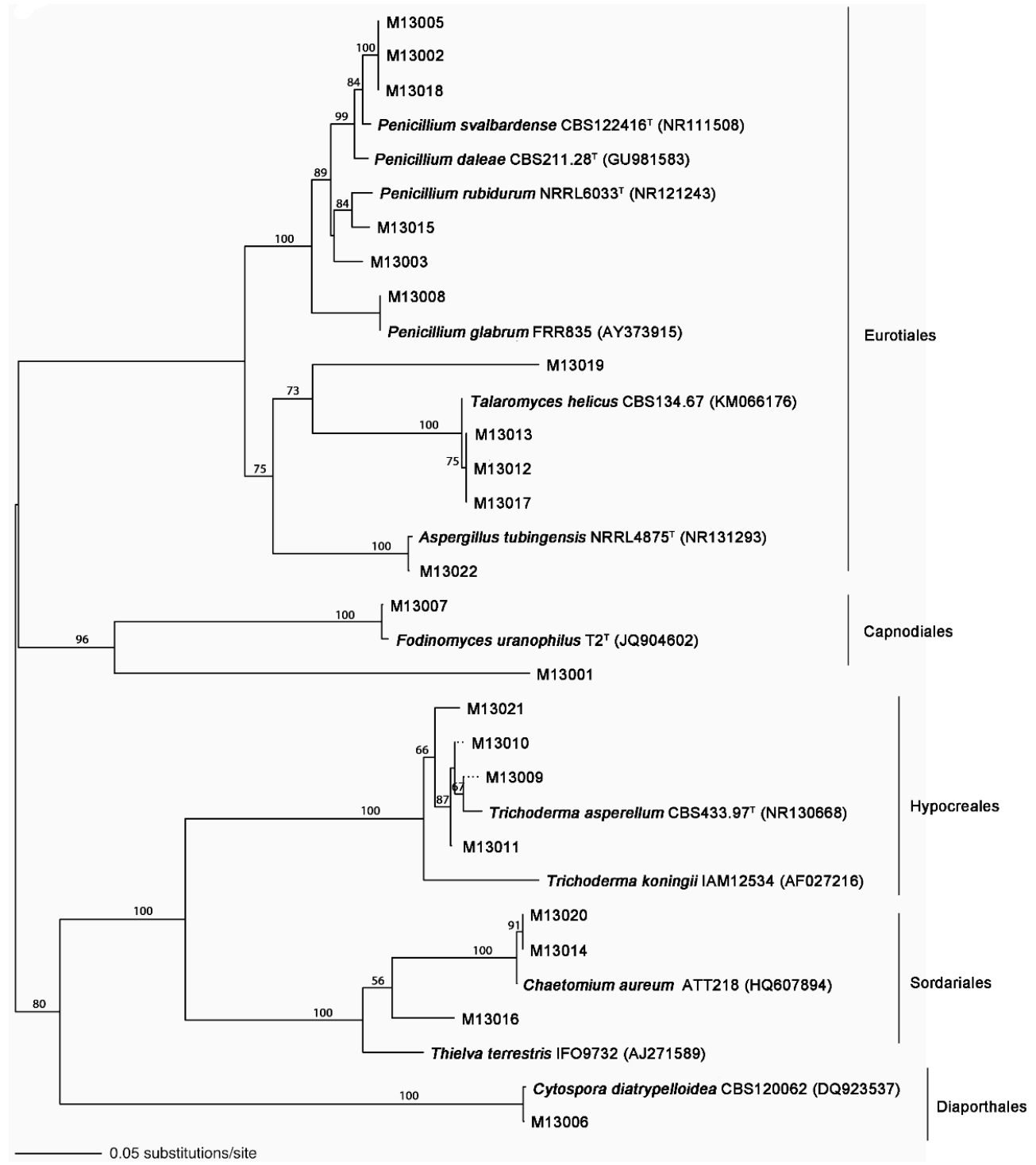

Figure 3. Neighbor-joining (NJ) tree showing the fungal isolates from M13. Numbers on branches correspond to Bootstrap index.

Our TEM and HAADF-STEM analyses of the M13 sediments showed fungal cells involved in biomineralization processes with minerals nucleated on fungal cell walls (Figure 4). The initial step of nucleation occurs on the outer-side of the fungal cell wall (Figure 4a). These nucleated minerals grow and aggregate on the cell wall until they form fibrous mineral structures outside of the fungal cell to cover it completely as shown in Figure 4A-D and Figure 5A-C. The EDX analyses of these structures (Figure $4 \mathrm{E}-\mathrm{H}$ and Figure $5 \mathrm{E}$ ) shows that the main components include $\mathrm{C}, \mathrm{O}$, and $\mathrm{Fe}$ as well as some Si and P. Although the main crystalline phase identified by XRD in the bulk sediment was hydronium-jarosite, the EDX analysis clearly show that none of the minerals associated with the analyzed fungal cell walls is an iron sulfate (Figures 4 and 5D), as sulfur should be present in a significant proportion with respect to the rest of the detected elements. In any case, we cannot rule out the possibility that the presence of hydronium-jarosite in the sediments is due to a purely abiotic process, since as stated above we could not evaluate its saturation index due to the absence of solubility data. We have to keep in mind that, in this study, biomineralization processes are taking place in 
natural sediments, not in pure culture, so it is difficult to determine in situ which fungal species are involved in these particular processes of biomineralization. However, the electron diffraction pattern obtained from the same mineral structures (data not shown) was poorly defined, suggesting that these phases are amorphous. Figure 5 shows a detail of the mineralized structures analyzed by TEM and HAADF-STEM, as well as the quantitative EDX.
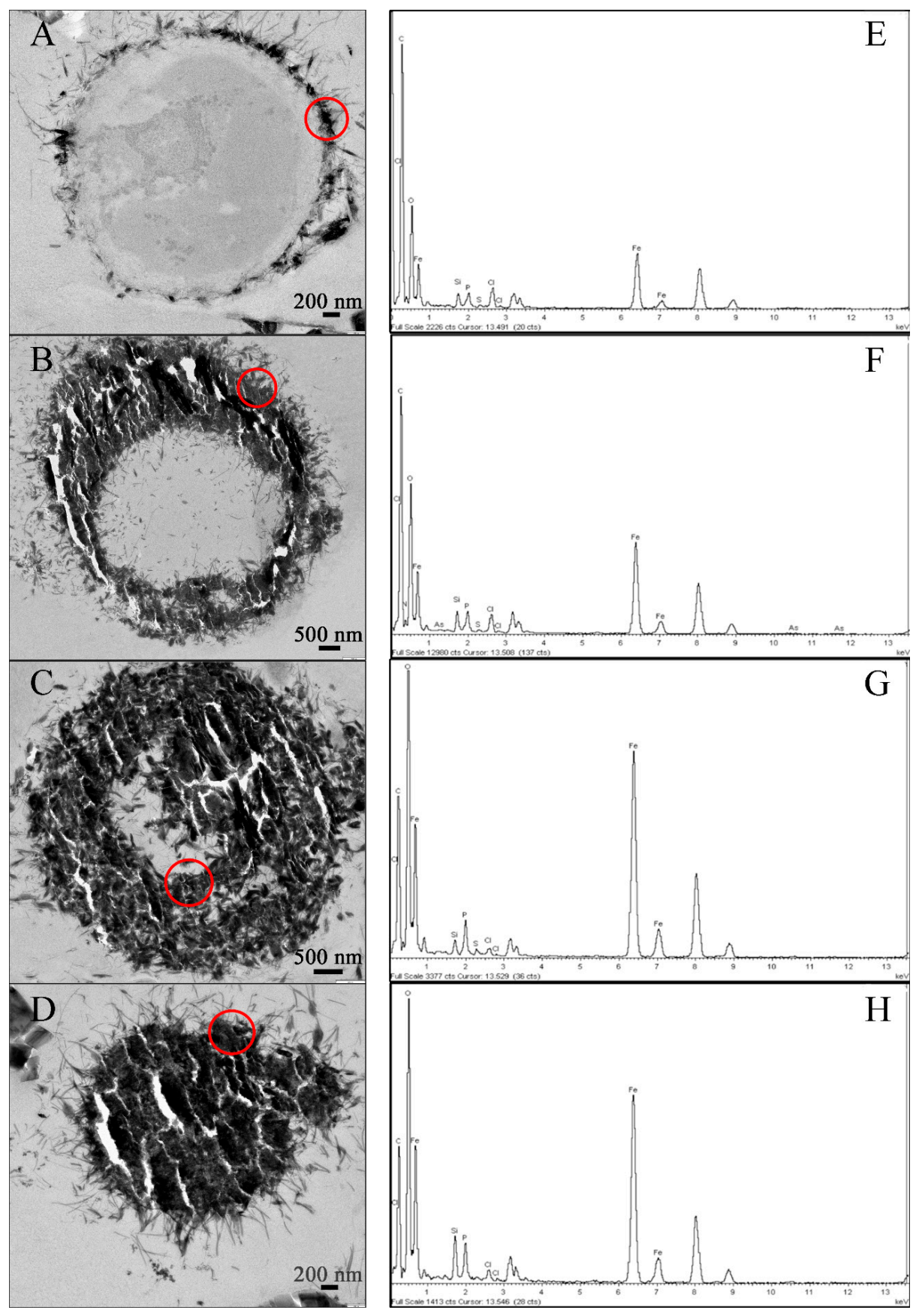

Figure 4. TEM and EDX analyses of the evolution of fungal mineralized structures from the M13 deposits. (A) Mineralization starts on the outer-side of the fungal cell wall, scale bar $200 \mathrm{~nm}$; (B) and (C) intermediate states of mineralization, scale bars $500 \mathrm{~nm}$; (D) mineral completely covering the fungal cell, scale bar $200 \mathrm{~nm}$. Circles indicate the areas where the EDX analyses were obtained; (E) Figure 4A EDX spectrum; (F) Figure 4B EDX spectrum; (G) Figure 4C EDX spectrum; (H) Figure 4D EDX spectrum. 

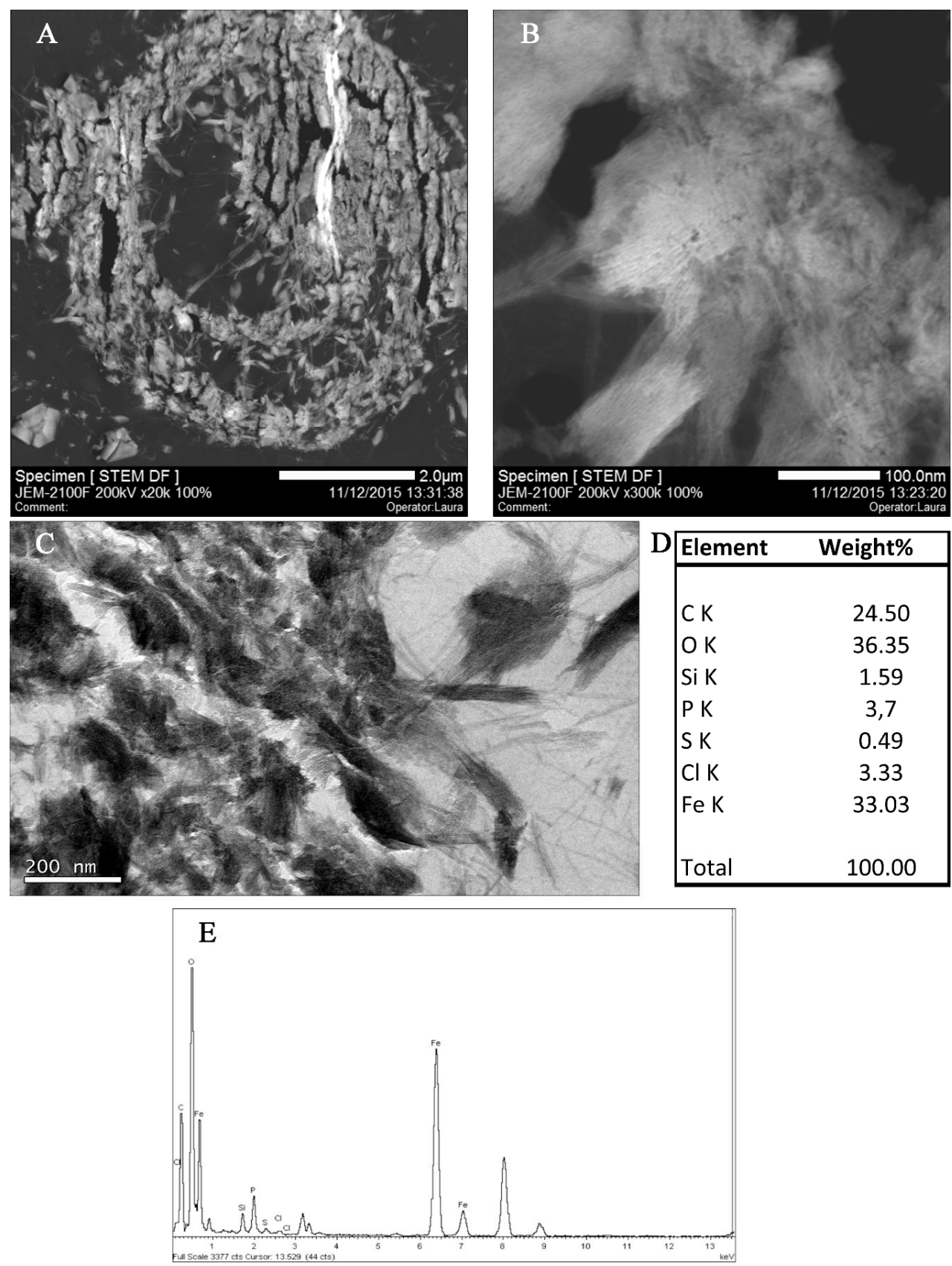

Figure 5. (A) HAADF-STEM image of Figure 4C; (B) HAADF-STEM image of a section of Figure 5A; (C) TEM image of a section of Figure 5A; (D) Quantitative analysis of Figure 5C; (E) EDX spectrum of Figure 5C.

In order to understand the possible mineral phase involved in this mineralization process, a detailed mapping analysis of the chemical composition of these mineral precipitates on the fungal wall was performed (Figure 6). Carbon (Figure 6A) is distributed throughout the image except in the areas where the mineral precipitate appears, so it is unlikely that it forms part of the mineral structure. With respect to Si and S (Figure 6C,F respectively), they are found randomly distributed throughout the biomineralized areas, but do not have a clear pattern. We interpret them as either precipitation as nano-particles of quartz (or another silica phase) or iron sulfates deposited on the mineralized structures. In fact, $\mathrm{Si}, \mathrm{S}$, and $\mathrm{Fe}$ are some of the major components of the water present in the M13 sampling area. 


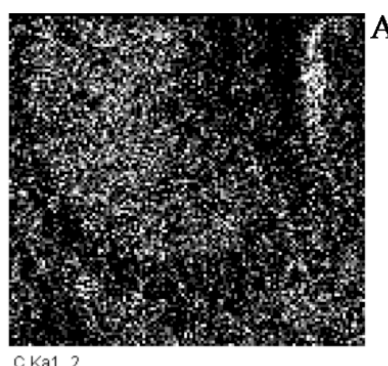

CKa1 2

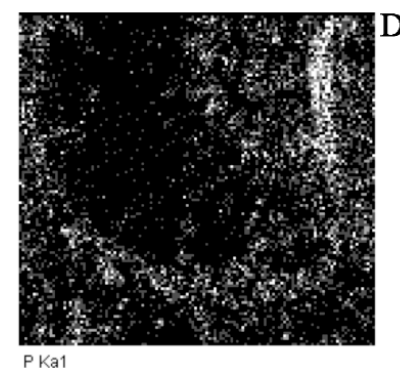
(C) Si; (D) P; (E) Fe; (F) S.
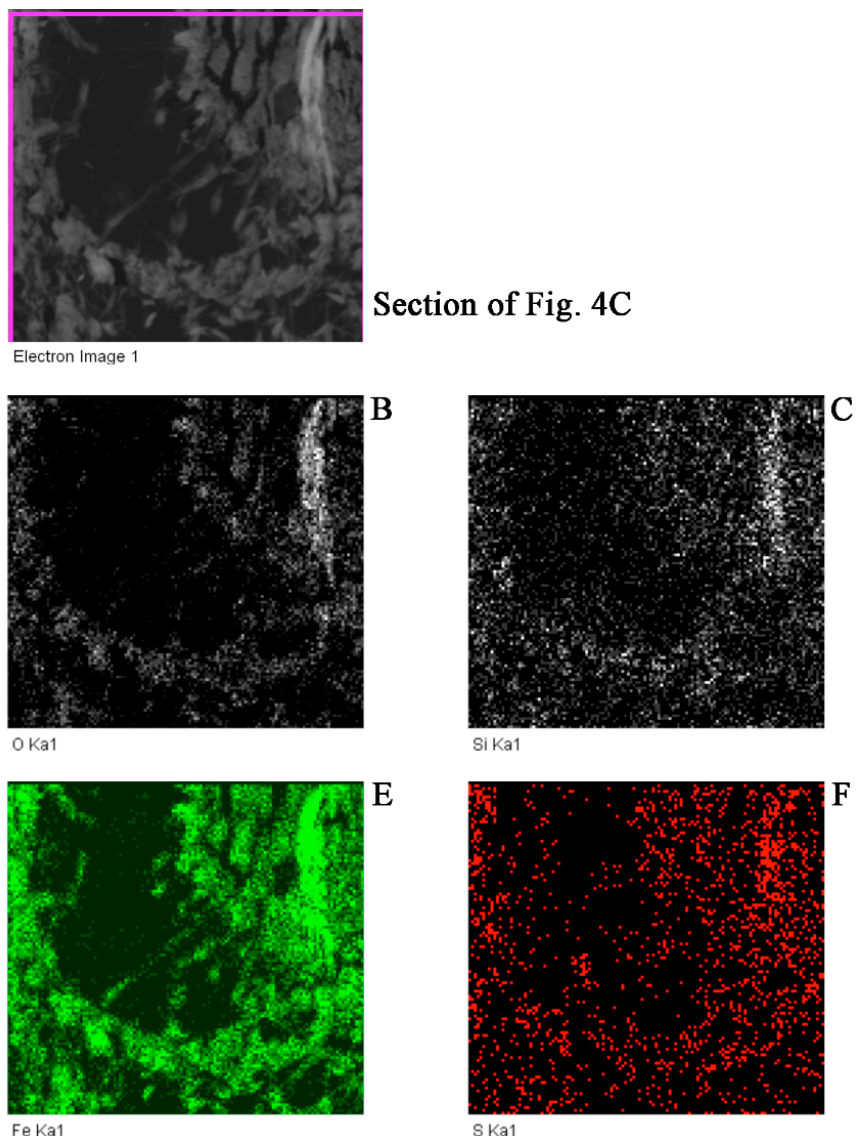

Figure 6. Mapping analysis of different elements of the sample showed in Figure 4C. (A) C; (B) O;

$\mathrm{P}, \mathrm{Fe}$, and $\mathrm{O}$ (Figure 6B,D,E respectively) show defined and consistent patterns associated with the mineralized structures. This observation could suggest that the precipitate mineral phase is an iron phosphate such as vivianite $\left(\left(\mathrm{Fe}^{2+}\right)_{3}\left(\mathrm{PO}_{4}\right)_{2} \cdot 8 \mathrm{H}_{2} \mathrm{O}\right)$, but a $\mathrm{Fe} / \mathrm{P}$ ratio of 9.8 (Figure 5) is far above the value expected for any known iron phosphate. In fact, reference [39] has shown that $\mathrm{Fe} / \mathrm{P}$ ratios in biogenic Fe-phosphates (vivianite and amorphous ferric phosphates) found in Lake Pavin were between 1.6 to 1.9. We cannot rule out that small nano-particles of iron phosphate coexist with another P-poor iron-rich phase. The most likely candidate with the observed chemical composition is an iron oxyhydroxide or an iron oxide. The observed fibrous texture suggests that it could be lepidocrocite $\left(\mathrm{Fe}^{3+} \mathrm{O}(\mathrm{OH})\right)$, a mineral of the goethite group which is supersatured in the hosting water $(\log \mathrm{Q} / \mathrm{K}>0.15$; Table 2). However, this data does not imply abiotic precipitation, because it depends on their precipitation kinetics $[40,41]$. Although the water of the river is oversaturated in goethite, it does not appear usually as a direct precipitate in AMD [6] due to its slow precipitation kinetics and its dependence on $\mathrm{pH}$. In contrast, in AMD, goethite generally precipitates at $\mathrm{pH}$ near neutrality and usually forms by transformation from Fe oxyhydroxyde-sulphates (e.g., [42]).

So, even though the concentration of ions in solution exceeds the solubility product for a mineral phase, precipitation will not occur due to this supersaturation if it is not enough to overcome the kinetic and thermodynamic barriers [22]. The presence of microorganisms (dead or alive) or even spores that develop charged surfaces, may promote this process. The microbial cell walls provide the pattern on which the nucleation may happen, and beat thermodynamic barriers to make mineral precipitation possible. The basis of this process is the ability of the microorganisms' surfaces to bind ions. The charged cell walls provide active interfacial sites for adsorption and complexation of dissolved aqueous metal species, inducing the nucleation and precipitation of minerals by reducing 
the activation energy barriers (e.g., $[15,43,44])$, resulting in a mineralized cellular matrix containing detectable concentrations of metallic ions that are not easily re-dissolved [45]. This is a passive process that can be carried out by living and dead fungal cells [18,30], where the resultant mineralogy depends on, in addition to growth conditions, the nature of the cell surface, the cellular microenviroment, and the presence of certain reactive anions in its cell walls. (e.g., [16]).

Our model for the precipitation of the iron-oxyhydroxide by fungal cell, involves the creation of $\mathrm{Fe}^{3+}$ rich microdomains by non-specific electrostatic interactions between the iron in solution, and charged reactive groups in the fungal cell walls that induce supersaturation and precipitation of a specific mineral. Phosphorous could well be present as small nano-particles within the iron-oxyhydroxide, or perhaps as one of the components of the fungal cell wall. According to [30,46] cell walls' negatively charged reactive groups include phosphate groups that could bind $\mathrm{Fe}^{3+}$ from the solution, reducing the activation energy barriers for nucleation.

This work refers to samples collected from a natural extreme environment in which fungal cultures have not intervened, so it is difficult to verify in situ which fungal species is/are responsible for this particular biomineralization process. We can foresee that fungi are involved in the geochemical cycles by forming minerals not expected because of their kinetic barriers of precipitation. Recently, it has been shown that another acidophilic fungi, Purpureocillium lilacinum, isolated from another location of the Tinto basin, was able to specifically produce hydronium-jarosite, another important mineral of this extreme acidic environment, in controlled laboratory conditions [21]. In natural systems (present work) abiotic precipitation could be challenging, but the presence of microorganisms can induce the precipitation of minerals in microenvironments by modifying the conditions of their immediate environments by concentrating ions on the cell wall, which induces supersaturation by reducing the activation energy barriers and acting as nucleation sites. Thus, the presence of important fungal communities in the Tinto basin, and their inherent ability to lead mineralization processes, makes them important geomicrobiological agents in the system, not only for their possible involvement in the processes of mineralization, but also in the weathering of other minerals and rocks.

\section{Conclusions}

Fungi, like bacteria and archaea, are involved in different geochemical cycles by dissolving minerals and rocks, and forming new ones. Our data show the presence of an important diverse fungal community inhabiting the area of study. The data also show the involvement of this fungal community in biomineralization processes. Nucleation occurs on the outerside of the fungal cell wall, and the formed mineral grows and aggregates until the mineral completely covers the fungal cell. The negatively charged cell walls provide active sites for adsoption, inducing nucleation and precipitation of minerals by reducing the energy barriers, forming minerals not expected because of their precipitation kinetic barriers. In natural systems, as the present work, abiotic precipitation of some minerals could be difficult, but the presence of microorganisms can induce their precipitation by modifying the thermodynamic conditions of their surrounding environment. All these factors indicate that fungal community should be considered important geological agents in the Río Tinto ecosystem not only for the role they may play in the formation of biogenic minerals in acidic environments, but also in the weathering of minerals and rocks, thus participating in the geochemical cycles of this natural extreme environment.

Acknowledgments: This work was supported by the European Research Council Advanced Grant ERC-250350/IPBSL. We also acknowledge Maria Teresa Rejas Marco and Milagros Guerra Rodriguez for their assistance in TEM sample preparation at the Electron Microscopy facility of CBMSO (UAM-CSIC), and Catalina del Moral and Diego Sánchez-Carrillo for their assistance.

Author Contributions: Monike Oggerin performed the laboratory tasks and carried out the experiments. Fernando Tornos performed geochemical analyses and calculations. Nuria Rodriguez performed some TEM analyses. Laura Pascual performed HAADF-STEM and mapping analyses. Monike Oggerin wrote the first draft of the manuscript. Fernando Tornos and Ricardo Amils assisted in preparing the manuscript, all authors read and approved the final version. 
Conflicts of Interest: The authors declare no conflict of interest.

\section{References}

1. Gómez-Ortiz, D.; Fernández-Remolar, C.D.; Granda, A.; Quesada, C.; Granda, T.; Prieto-Ballesteros, O.; Molina, A.; Amils, R. Identification of the subsurface sulfide bodies responsible for acidity in Río Tinto source water, Spain. Earth Planet. Sci. Lett. 2014, 391, 36-41. [CrossRef]

2. Amils, R.; González-Toril, E.; Fernández-Remolar, D.; Gómez, F.; Rodríguez, N.; Durán, C. Interaction of the sulfur and iron cycles in the Tinto River ecosystem. Rev. Environ. Sci. Biotechnol. 2002, 1, 299-309. [CrossRef]

3. González-Toril, E.; Llobet-Brossa, E.; Casamayor, E.O.; Amann, R.; Amils, R. Microbial ecology of an extreme acidic environment, the Tinto River. Appl. Environ. Microbiol. 2003, 69, 4853-4865. [CrossRef] [PubMed]

4. Nordstram, D.K.; Southam, G. Geomicrobiolgy of sulfide mineral oxidation. Rev. Mineral. Geochem. 1997, 35, 361-390.

5. Dutrizac, J.E.; Jambor, J.L. Jarosites and their application in hydrometallurgy. Rev. Mineral. Geochem. 2000, 40, 405-453. [CrossRef]

6. Fernández-Remolar, D.; Morris, R.V.; Gruener, J.E.; Amils, R.; Knoll, A.H. The Río Tinto Basin, Spain: Mineralogy, sedimentary geobiology, and implications for interpretation of outcrop rocks at Meridiani Planum. Mars Earth Planet. Sci. Lett. 2005, 240, 149-167. [CrossRef]

7. López-Archilla, A.I.; Marín, I.; Amils, R. Microbial community composition and ecology of an acidic aquatic environment: The Tinto River, Spain. Microb. Ecol. 2001, 41, 20-35. [PubMed]

8. Oggerin, M.; del Moral, C.; Rodriguez, N.; Amils, R. Fungal diversity in Río Tinto (IPB) the largest natural extreme acidic ecosystem on Earth surface. In preparation.

9. Amils, R.; Fernández-Remolar, D.; The IPBSL Team. Río Tinto: A geochemical and mineralogical terrestrial analogue of Mars. Life 2014, 4, 511-534. [CrossRef] [PubMed]

10. Brown, M.T.; Hall, I.R. Metal tolerance in fungi. In Heavy Metal Tolerance in Plants: Evolutionary Aspects; Shaw, J., Ed.; CRC Press: Boca Raton, FL, USA, 1990; pp. 95-104.

11. Gadd, G.M. Bacterial and fungal geomicrobiology: A problem with communities? Geobiology 2008, 6, $278-284$. [CrossRef] [PubMed]

12. Lowestam, H.A. Mineral formed by organisms. Science 1981, 211, 1126-1131. [CrossRef]

13. Beveridge, T.J. Role of cellular design in bacterial metal accumulation and ineralization. Annu. Rev. Microbiol. 1989, 43, 147-171. [CrossRef] [PubMed]

14. Bazylinski, D.A. Bacterial mineralization. In Encyclopedia of Materials: Science and Technology; Buschow, K.H.J., Cahn, R.W., Flemings, M.C., Ilschner, B., Kramer, E.J., Mahajan, S., Eds.; Elsevier: Amsterdam, The Netherlands, 2001; pp. 441-448.

15. Konhauser, K.O. Diversity of bacterial iron mineralization. Earth Sci. Rev. 1998, 43, 91-121. [CrossRef]

16. Beveridge, T.J.; Murray, R.G.E. Uptake and retention of metals by cell walls of Bacillus subtilis. J. Bacterial. 1976, 127, 1502-1518.

17. Urrutia, M.M.; Kemper, M.; Doyle, R.; Beveridge, T.J. The membrane-induced proton motive force influences the metal binding ability of Bacillus subtilis cell walls. Appl. Environ. Microbiol. 1992, 58, 3837-3844.

18. Gadd, G.M.; Rhee, Y.J.; Stephenson, K.; Wei, Z. Geomycology: Metals, actinides and biominerals. Environ. Microbiol. Rep. 2012, 4, 270-296. [CrossRef] [PubMed]

19. Schwertmann, U.; Cornell, R.M. General preparative techniques. In Iron Oxides in the Laboratory: Preparation and Characterization, 2nd ed.; Wiley VCH Verlag: Weinheim, Germany, 2007; pp. 19-25.

20. Martín, J.D. Using XPowder-A Sofware Package for Powder X-Ray Diffraction Analysis, 2004; D.L.GR-1001/04, ISBN: 84-609-1497-6, 105p. Spain. Available online: http:// www.xpowder.com/ (accessed on 1 January 2010).

21. Oggerin, M.; Tornos, F.; Rodríguez, N.; del Moral, C.; Sánchez-Román, M.; Amils, R. Specific jarosite biomineralization by Purpureocillium lilacinum, an acidophilic fungi isolated from Río Tinto. Environ. Microbiol. 2013, 15, 2228-2237. [CrossRef] [PubMed]

22. Bethke, C.M. Geochemical and Biogeochemical Modeling; Cambridge University Press: Cambridge, UK, 2008.

23. Wolery, T.J. EQ3/6, a Software Package for Geochemical Modeling of Aqueous Systems: Package Overview and Installation Guide (Version 7.0); Lawrence Livermore National Laboratory: Livermore, CA, USA, 1992; p. 66. 
24. Larkin, M.A.; Blackshields, G.; Brown, N.P.; Chenna, R.; McGettigan, P.A.; McWilliam, H.; Higgins, D.G. Clustal W and Clustal X version 2.0. Bioinformatics 2007, 23, 2947-2948. [CrossRef] [PubMed]

25. Rambaut, A. Se-Al Carbon Software, 1996. Available online: http://tree.bio.ed.ac.uk/software/seal/ (accessed on 1 January 2005).

26. Swofford, D.L. Phylogenetic Analysis Using Parsimony ( ${ }^{*}$ and Other Methods); Version 4; Sinauer Associates: Sunderland, MA, USA, 2002.

27. Felsenstein, J. Confidence limits on phylogenies: An approach using the bootstrap. Evolution 1985, 39, 783-791. [CrossRef]

28. Tornos, F. Environment of formation and styles of volcanogenic massive sulfides: The Iberian Pyrite Belt. Ore Geol. Rev. 2006, 28, 259-307. [CrossRef]

29. Wei, Z.; Liang, X.; Pendlowski, H.; Hillier, S.; Suntornvongsagul, K.; Sihanonth, P.; Gadd, G.M. Fungal biotransformation of zinc silicate and sulfide mineral ores. Environ. Microbiol. 2013, 15, 2173-2186. [CrossRef] [PubMed]

30. Sterflinger, K. Fungi as geologic agents. Geomicrobiol. J. 2000, 17, 97-124. [CrossRef]

31. Gadd, G.M. Geomycology: Biogeochemical transfor-mations of rocks, minerals, metals and radionuclides by fungi, bioweathering and bioremediation. Mycol. Res. 2007, 111, 3-49. [CrossRef] [PubMed]

32. Gueidan, C.; Ruibal, C.; de Hoog, G.S.; Schneider, H. Rock-inhabiting fungi originated during periods of dry climate in the late Devonian and middle Triassic. Fungal Biol. 2011, 115, 987-996. [CrossRef] [PubMed]

33. Gorbushina, A.A.; Kotlova, E.R.; Sherstneva, O.A. Cellular responses of microcolonial rock fungi to long-term desiccation and subsequent rehydration. Stud. Mycol. 2008, 61, 91-97. [CrossRef] [PubMed]

34. Burford, E.P.; Fomina, M.; Gadd, G.M. Fungal involvement in bioweathering and biotransformation of rocks and minerals. Mineral. Mag. 2003, 67, 1127-1155. [CrossRef]

35. Gadd, G.M. Metals, minerals and microbes: Geomicrobiology and bioremediaton. Microbiology 2010, 156, 609-643. [CrossRef] [PubMed]

36. Amaral-Zettler, L.A.; Gomez, F.; Zettler, E.; Keenan, B.G.; Amils, R.; Sogin, M.L. Eukaryotic diversity in Spain's River of Fire. Nature 2002, 417, 137. [CrossRef] [PubMed]

37. Baker, B.J.; Lutz, M.A.; Dawson, S.C.; Bond, P.L.; Banfield, J.F. Metabolically active eukaryotes in extremely acidic mine drainage. Appl. Environ. Microbiol. 2004, 70, 6264-6271. [CrossRef] [PubMed]

38. Chaput, D.L.; Hansel, C.M.; Burgos, W.D.; Santelli, C.M. Profiling microbial communities in manganese remediation systems treating coal mine drainage. Appl. Environ. Microbiol. 2015, 81, 2189-2198. [CrossRef] [PubMed]

39. Cosmidis, J.; Benzerara, K.; Morin, G.; Busigny, V.; Lebeau, O.; Jézéquel, D.; Noël, V.; Dublet, G.; Othmane, G. Biomineralization of iron-phosphates in the water column of Lake Pavin (Massif Central, France). Geochim. Coschim. Acta 2014, 126, 78-96. [CrossRef]

40. Schwertmann, U.; Cornell, R.M. Goethite. In Iron Oxides in the Laboratory: Preparation and Characterization, 2nd ed.; Wiley VCH Verlag: Weinheim, Germany, 2007; pp. 67-92.

41. Schwertmann, U.; Cornell, R.M. Lepidocrocite. In Iron Oxides in the Laboratory: Preparation and Characterization, 2nd ed.; Wiley VCH Verlag: Weinheim, Germany, 2007; pp. 93-97.

42. Bigham, J.M.; Nordstroma, D.K. Iron and aluminium hydroxysulfates from acid sulfate waters. Rev. Mineral. Geochem. 2000, 40, 351-403. [CrossRef]

43. Fortin, D.; Ferris, F.G.; Beveridge, T.J. Surface mediated mineral development by bacteria. In Geomicrobiology: Interactions between Microbes and Minerals, Reviews in Mineralogy; Banfield, J.F., Nealson, K.H., Eds.; Mineralogical Society of America: Washington, DC, USA, 1997; Volume 35, p. 161.

44. Mann, S. Molecular recognition in biomineralization. Nature 1988, 332, 119-124. [CrossRef]

45. Beveridge, T.J.; Fyfe, W.S. Metal fixation by bacterial cell walls. Can. J. Earth Sci. 1985, 22, $1893-1898$. [CrossRef]

46. Siegel, S.M.; Galun, M.; Siegel, B.Z. Filamentous fungi as metal biosorbents: A review. Water Air Soil Pollut. 1990, 53, 335-344. [CrossRef]

(C) 2016 by the authors; licensee MDPI, Basel, Switzerland. This article is an open access article distributed under the terms and conditions of the Creative Commons Attribution (CC-BY) license (http://creativecommons.org/licenses/by/4.0/). 